\title{
Ocena powtarzalności badań audiometrycznych wykonywanych u dzieci w wieku przedszkolnym
}

\section{Evaluation of repeatability of audiometric tests in preschool children}

\author{
Paulina Dziedzic ${ }^{2}$, Krzysztof Kochanek ${ }^{1,2}$, Adam Piłka ${ }^{1}$, Henryk Skarżyński ${ }^{1}$ \\ ${ }^{1}$ Instytut Fizjologii i Patologii Słuchu, Światowe Centrum Słuchu, Warszawa/Kajetany \\ ${ }^{2}$ Uniwersytet im. Marii Curie-Skłodowskiej, Zakład Logopedii i Językoznawstwa Stosowanego, Lublin
}

Adres autora: Paulina Dziedzic, Szczepańcowa, ul. Słoneczna 29, 38-457 Chorkówka, e-mail: paula.dzie@poczta.fm

\section{Streszczenie}

Wstęp: Badania przesiewowe słuchu u małych dzieci są bardzo ważne, ponieważ pozwalają na wczesne wykrycie zaburzeń słuchu oraz wdrożenie odpowiedniej terapii umożliwiającej prawidłowy rozwój dziecka. Powinny obejmować nie tylko noworodki, lecz także dzieci w wieku przedszkolnym oraz szkolnym. Znana jest wartość audiometrycznych badań przesiewowych u dzieci $\mathrm{w}$ wieku szkolnym, natomiast niewiele jest doniesień na temat zastosowania audiometrii w badaniach przesiewowych u dzieci młodszych - w wieku 4-5 lat. Przed zastosowaniem audiometrii progowej w badaniach przesiewowych słuchu u małych dzieci, należy sprawdzić, jaka jest powtarzalność tych pomiarów, aby uzyskać odpowiedź na pytanie, czy w badaniach przesiewowych słuchu można oprzeć się na jednokrotnym pomiarze, czy też procedura badania wymaga wykonania 2-3-krotnych pomiarów.

Cel: Ocena powtarzalności audiometrycznych badań przesiewowych u dzieci w wieku przedszkolnym

Materiał i metody: Badaniami objęto grupę 20 dzieci w wieku 4-5 lat, uczęszczających do przedszkola. U wszystkich osób wykonano trzykrotny pomiar progu słyszenia, w losowo wybranym uchu. Badania wykonywano w odstępach dwudniowych, o tej samej porze dnia, w tym samym pomieszczeniu. Pomiary prowadzono procedurą góra-dół dla przewodnictwa powietrznego dla częstotliwości 500, 1000, 2000, 4000 i $8000 \mathrm{~Hz}$.

Wyniki: W obu grupach dzieci średnie wartości progu słyszenia dla poszczególnych częstotliwości, wyznaczone podczas trzeciego badania, były nieznacznie niższe niż w badaniu pierwszym i drugim. W obu grupach wiekowych ponad 95\% różnic pomiędzy pomiarami nie przekraczało $10 \mathrm{~dB}$, co świadczy o dużej powtarzalności badania audiometrycznego. W kolejnych badaniach skracał się czas pomiarów.

Wnioski: Przeprowadzone badania wykazały, że zarówno u dzieci w wieku 5 lat, jak i 4 lat możliwe jest wykonanie wiarygodnego badania audiometrycznego.

Słowa kluczowe: audiometryczny próg słyszenia • badania przesiewowe słuchu • test-retest

\section{Abstract}

Introduction: Hearing screening in small children is very important, as it enables early detection of hearing disorders and implementation of the appropriate therapy allowing the child to develop normally. Hearing screening should involve not only newborns, but also school- and preschool- age children. The value of the audiometric screening tests in school-age children is well known, but there are still only a few reports on using the audiometric tests in screening examinations in younger children $-4-5$ years olds. Before using the audiometric tests in hearing screening in small children it is necessary to verify the repeatability of measurements, to ascertain if hearing screening may be based on single measurement, or should the procedure include 2-3 repeated masurements.

Aim: The aim of this study was to evaluate the repeatability of audiometric screening tests in preschool-age children.

Material and methods: Study encompassed 20 children aged 4-5 years, going to nursery school, divided into 2 groups according to age. In all subjects hearing threshold was measured three times in random ear. Tests were performed in two-day 
intervals, at the same time of the day, in the same room. Measurements were performed using the up-and-down procedure for air conduction in frequencies of 500, 1000, 2000, 4000 and $8000 \mathrm{~Hz}$.

Results and conclusions: In both groups of children mean values of hearing thresholds for each frequency measured in third repetition were slightly lower than in first and second tests. In both age-groups more than $95 \%$ of differences between measurements did not exceed $10 \mathrm{bD}$, which demonstrates high repeatability of audiometric test. Time needed to perform measurement was shorter with each repetition. These results confirm that both in 5-year olds and in 4-year olds it is possible to perform reliable audiometric tests.

Key words: hearing threshold • hearing screening • test-retest

\section{Wstęp}

Zaburzenia słuchu mogą pojawić się w każdym momencie życia człowieka. Ich wielkość i rodzaj uwarunkowane są wieloma czynnikami, m.in. fizjologicznymi, zmianami anatomicznymi, czynnikami genetycznymi oraz środowiskowymi [1-4].

Wraz z wiekiem obserwujemy wzrost częstości występowania zaburzeń słuchu. Wyniki badań przesiewowych słuchu u noworodków prowadzonych w różnych krajach, w tym również w Polsce, pokazują, że w okresie noworodkowym wrodzone zaburzenia słuchu stwierdza się u ok. 1-2 dzieci na 1000 urodzeń [5-8]. Wśród dzieci w wieku szkolnym częstość występowania zaburzeń słuchu wzrasta do kilkunastu procent [9-16]. W pracy Kruszyńskiej (2013) wykazano, że w badaniach tych samych dzieci częstość wyników dodatnich pomiędzy badaniem w okresie noworodkowym i szkolnym wzrasta ponad 10 razy [17].

Do potencjalnych przyczyn występowania zaburzeń słuchu w okresie szkolnym zaliczyć należy stany zapalne ucha środkowego, infekcje górnych dróg oddechowych, zaburzenia genetyczne, ubytki pohałasowe - związane ze słuchaniem głośnej muzyki przez słuchawki, choroby zakaźne oraz zapalenie opon mózgowych czy urazy mechaniczne, związane z np. nieumiejętnym czyszczeniem ucha [18-23].

Wykonywanie badań przesiewowych słuchu jest wskazane w różnych okresach życia człowieka. W Polsce oraz w wielu krajach na świecie coraz szerzej wdrażane są programy dotyczące wczesnego wykrywania, leczenia i rehabilitacji zaburzeń słuchu. Współczesne możliwości i osiągnięcia medyczne, teleinformatyczne czy organizacyjne pozwalają na prowadzenie programów badań obejmujących swym zasięgiem całe lub wybrane regiony. O celowości wdrażania masowych programów przesiewowych słuchu świadczą wyniki badań. Wykazują one, że występowanie zaburzeń słuchu w pierwszych latach życia może negatywnie wpływać nie tylko na rozwój mowy, lecz także na rozwój emocjonalny i poznawczy dziecka oraz jego funkcjonowanie we wszystkich sferach życia rodzinnego i społecznego na każdym etapie edukacyjnego rozwoju [14,24,25].

$\mathrm{W}$ badaniach przesiewowych słuchu u dzieci w wieku szkolnym mogą być wykorzystywane zarówno metody obiektywne (emisje otoakustyczne, audiometria impedancyjna), jak i metody audiometryczne [26-30].

Metody audiometryczne stosowane są bardzo często w badaniach przesiewowych u dzieci w wieku szkolnym, młodzieży i osób dorosłych. Niewiele jest natomiast doniesień w piśmiennictwie na temat wykorzystania tej metody w badaniach przesiewowych u dzieci w wieku przedszkolnym. ASHA (American Speech-Language-Hearing Association) do prowadzenia badań przesiewowych w tej grupie wiekowej zaleca stosowanie audiometrii zabawowej (ang. Conditioned Play Audiometry, CPA) lub audiometrii tonalnej dla tonów o natężeniu 20 dB HL o częstotliwościach 1000, 2000 i $4000 \mathrm{~Hz}$. W niektórych przypadkach możliwe jest także wykonanie audiometrii wspomaganej bodźcem wzrokowym (ang. Visual Reinforcement Audiometry, VRA).

Wiadomo, że wykonanie wiarygodnego badania progu słyszenia wymaga nie tylko dużego doświadczenia osoby prowadzącej badanie, lecz także zapewnienia dobrej współpracy pomiędzy osobą badaną a osobą przeprowadzającą badanie. Dzieci w wieku przedszkolnym badanie audiometryczne słuchu mają wykonywane zazwyczaj po raz pierwszy w życiu i wymaga ono więcej czasu na wypracowanie pożądanych reakcji na prezentowany bodziec. Można założyć, że powtarzalność audiometrycznych badań progowych będzie się różnić od powtarzalności analogicznych badań wykonywanych u dzieci starszych i osób dorosłych.

Celem pracy była ocena powtarzalności wyników audiometrycznych badań przesiewowych u dzieci w wieku przedszkolnym.

\section{Materiał i metody}

Badaniami objęto dwie 10-osobowe grupy dzieci w wieku 4 i 5 lat (7 dziewczynek i 13 chłopców). Badanie obejmowało trzykrotne wyznaczenie wartości progu słyszenia metodą audiometryczną dla przewodnictwa powietrznego. Pierwsze badanie obejmowało wyznaczenie progu słyszenia w obojgu uszach, natomiast w drugim i trzecim pomiarze progi wyznaczono tylko w jednym uchu, aby skrócić czas badania dziecka, przy czym dążono do tego, by odsetek uszu prawych i lewych był zbliżony. U 11 dzieci badania przeprowadzono w uchu lewym, u 9 dzieci w uchu prawym. Badania wykonywano w odstępach dwudniowych, o tej samej porze dnia.

Badania progu słyszenia prowadzono za pomocą mobilnego urządzenia - Platformy Badań Zmysłów umożliwiającej wykonywanie badań przesiewowych w szkołach. U każdego dziecka wyznaczono wartości progów słyszenia dla przewodnictwa powietrznego dla częstotliwości: 500, 1000, 2000, 4000, 8000 Hz. Przy wyznaczaniu progów słyszenia wykorzystywano procedurę Hughson \& Westlake [31].

Badania wykonywano w przedszkolu, w pomieszczeniu znajdującym się w najcichszej części budynku. Dziecko 

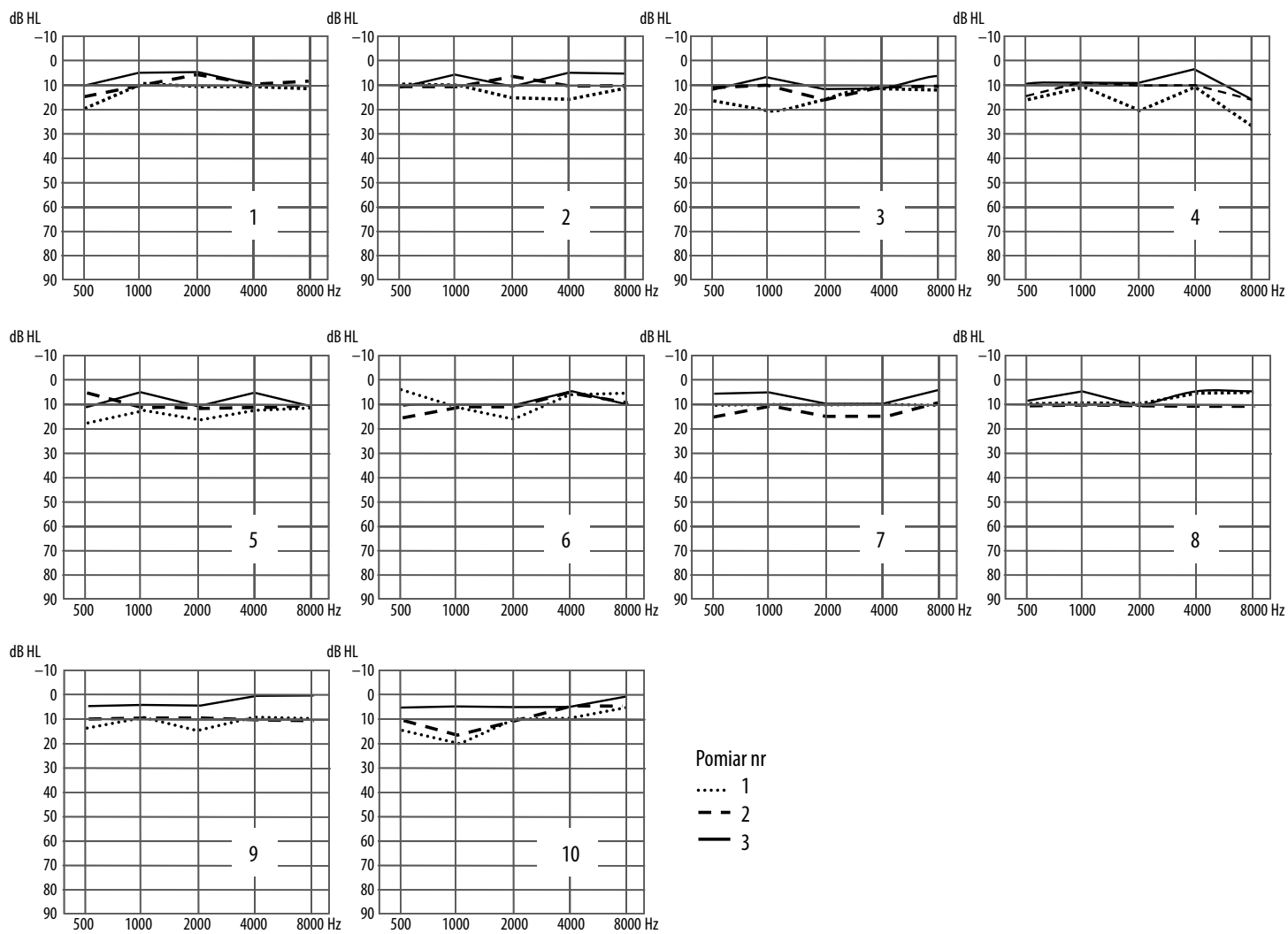

$$
\begin{aligned}
& \text { Pomiar nr } \\
& \begin{array}{l}
\ldots . .1 \\
-
\end{array} \\
& -3
\end{aligned}
$$

Rycina 1. Indywidualne audiogramy dzieci 5-letnich wykonane podczas trzech badań

Figure 1. Individual audiograms of 5 -year olds produced during in three test repetitions
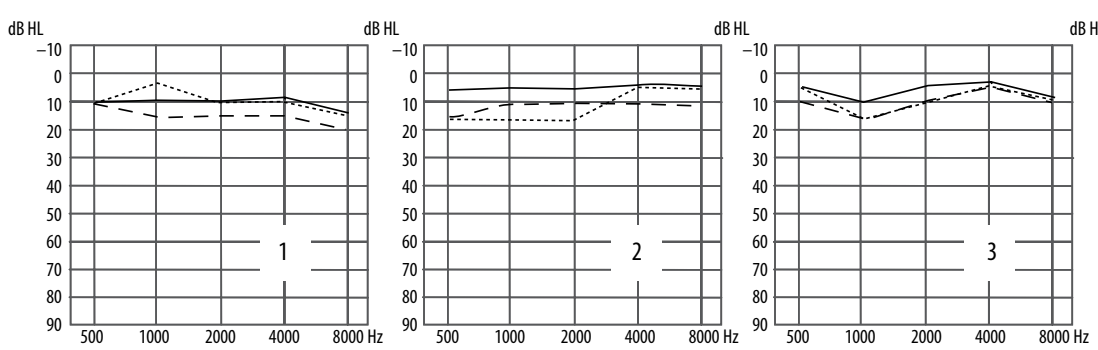

$\mathrm{dBHL}$
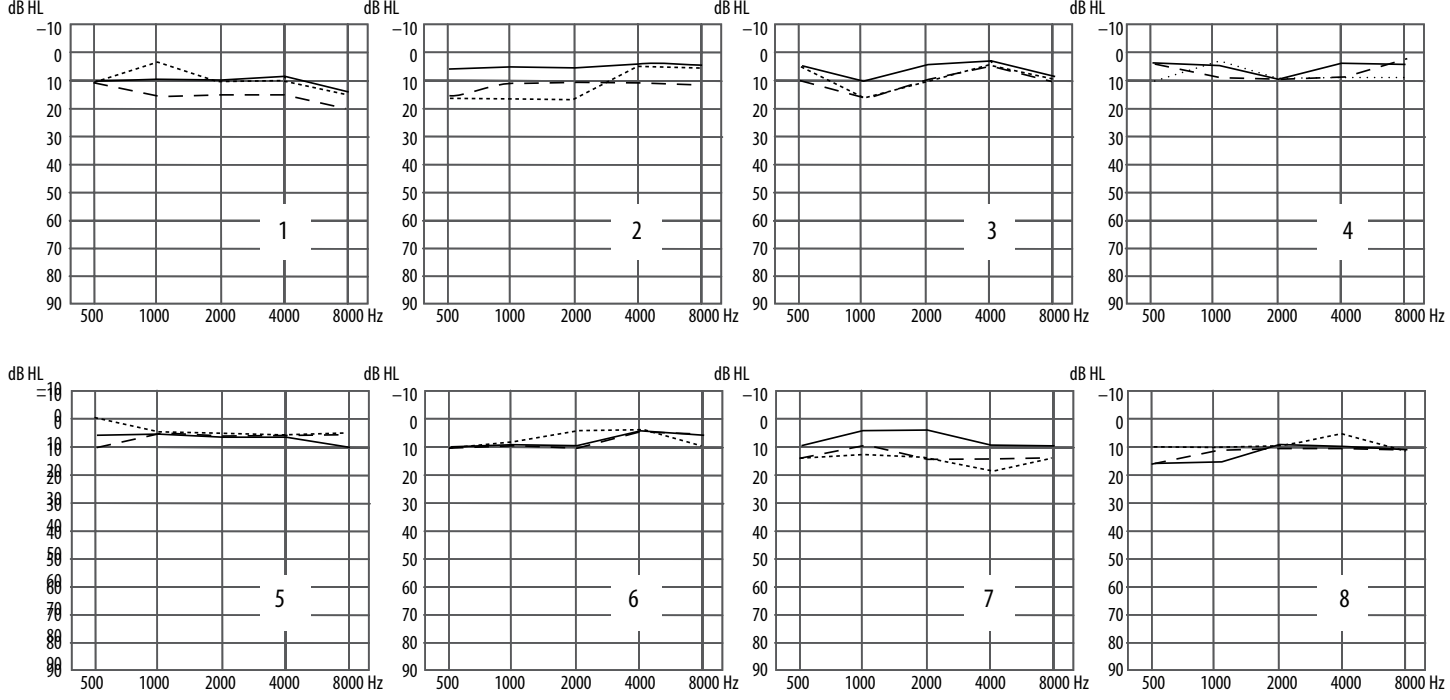

$\mathrm{AB} \mathrm{HL}$
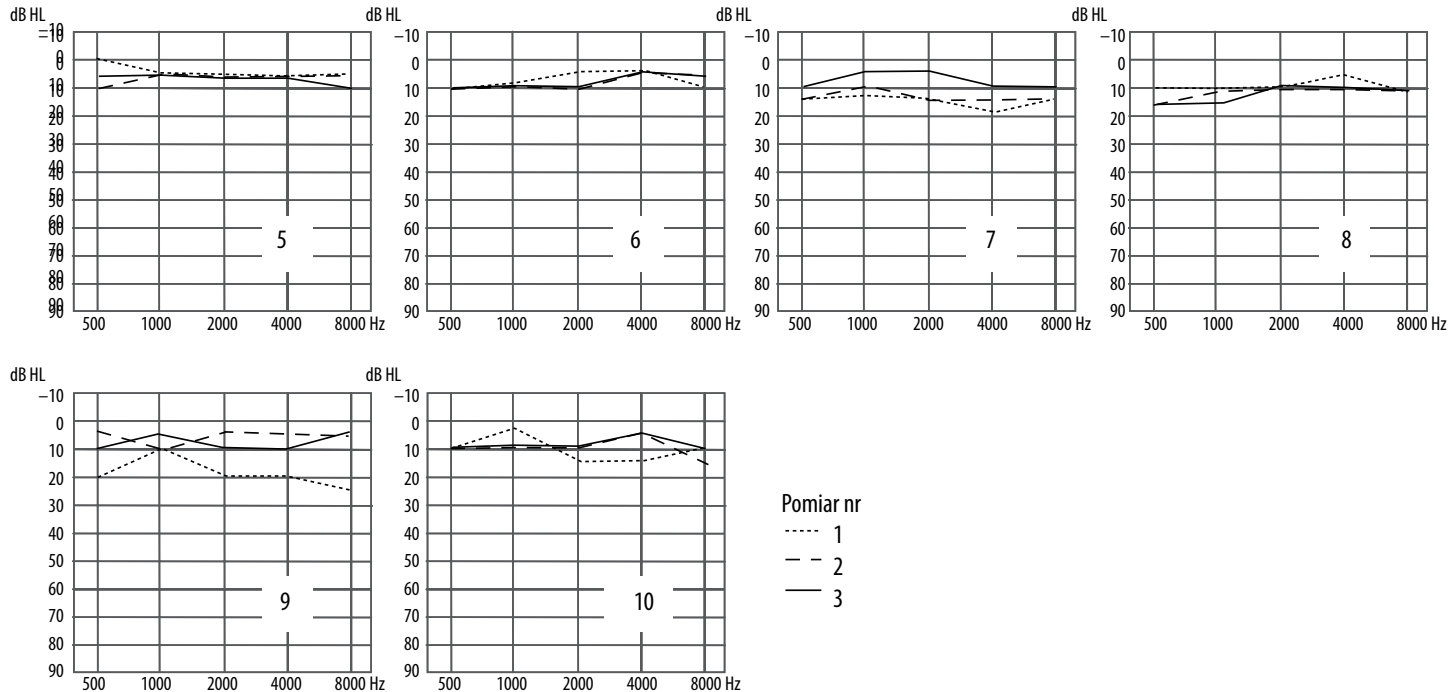

$$
\begin{gathered}
\text { Pomiar nr } \\
\cdots-1 \\
--2 \\
-3
\end{gathered}
$$

Rycina 2. Indywidualne audiogramy dzieci 4-letnich wykonane podczas trzech badań

Figure 2. Individual audiograms of 4-year olds produced in three test repetitions 
Tabela 1. Średnie i odchylenia standardowe wartości progów dla poszczególnych częstotliwości wyznaczonych w kolejnych badaniach z podziałem na grupy wiekowe

Table 1. Mean values and standard deviation of thresholds for each frequency determined in each test repetition, by age groups

\begin{tabular}{|c|c|c|c|c|c|c|c|}
\hline \multirow{2}{*}{ Wiek dziecka } & \multirow{2}{*}{ Częstotliwość } & \multicolumn{2}{|c|}{ Badanie 1} & \multicolumn{2}{|c|}{ Badanie 2} & \multicolumn{2}{|c|}{ Badanie 3} \\
\hline & & $\overline{\mathbf{x}}$ & SD & $\overline{\mathbf{x}}$ & SD & $\overline{\mathbf{x}}$ & SD \\
\hline \multirow{5}{*}{4 lata } & 500 & 10,5 & 5,5 & 10,5 & 3,7 & 8,5 & 3,4 \\
\hline & 1000 & 10,5 & 5,5 & 10,5 & 2,8 & 8,0 & 3,5 \\
\hline & 2000 & 11,5 & 4,7 & 10,0 & 3,3 & 8,0 & 2,6 \\
\hline & 4000 & 10,0 & 6,2 & 8,5 & 4,1 & 7,0 & 2,6 \\
\hline & 8000 & 11,0 & 5,7 & 10,0 & 5,3 & 8,5 & 3,4 \\
\hline \multirow{5}{*}{5 lat } & 500 & 13,0 & 4,2 & 11,5 & 3,4 & 8,5 & 2,4 \\
\hline & 1000 & 12,0 & 4,2 & 10,5 & 1,6 & 6,0 & 2,1 \\
\hline & 2000 & 13,5 & 3,4 & 10,0 & 3,3 & 8,5 & 2,4 \\
\hline & 4000 & 9,5 & 2,8 & 9,5 & 2,8 & 6,0 & 3,2 \\
\hline & 8000 & 10,0 & 5,8 & 10,0 & 2,4 & 6,5 & 4,7 \\
\hline
\end{tabular}

siedziało tyłem do osoby badanej i sygnalizowało słyszenie tonu poprzez podniesienie ręki. W niektórych przypadkach podczas badania obecny był opiekun grupy przedszkolnej.

Analizę wyników badań przeprowadzono z wykorzystaniem Bazy Wiedzy - naukowej platformy informatycznej przetwarzania wyników badań przesiewowych Instytutu Fizjologii i Patologii Słuchu. W pracy dokonano oceny wpływu wieku dziecka oraz kolejnych badań na wartości progu słyszenia dla poszczególnych częstotliwości. Przeprowadzono również analizę wielkości różnic pomiędzy pomiarami oraz oceniono czas trwania badania w kolejnych próbach. Analizy statystyczne wykonano za pomocą testu ANOVA dla układów czynnikowych. Indywidualnych porównań dokonano, w zależności od charakterystyki rozkładu wyników badań, na podstawie testu t-Studenta dla prób powiązanych lub niepowiązanych lub za pomocą nieparametrycznych testów kolejności par Wilcoxona lub testu U Manna-Whitneya. Dla wszystkich testów przyjęto poziom istotności $\mathrm{p}<0,05$.

\section{Wyniki}

Na rycinach 1 i 2 przestawiono indywidualne audiogramy uzyskane u dzieci 5-letnich (rycina 1) i 4-letnich (rycina 2) podczas kolejnych badań.

Analiza indywidualnych audiogramów wykazała, że zarówno u dzieci w wieku 4, jak i 5 lat różnice pomiędzy kolejnymi pomiarami nie przekraczały w większości przypadków $5 \mathrm{~dB}$. Jedynie u nielicznych dzieci dla niektórych częstotliwości zaobserwowano różnice większe niż $15 \mathrm{~dB}$.

Analiza indywidualnych audiogramów wykazała również, że wartości progu dla kolejnych częstotliwości wyznaczone podczas trzeciego pomiaru były u większości badanych dzieci nieco niższe (uzyskany wynik wskazywał na lepszą wartość progu słyszenia) niż w pozostałych pomiarach.
Przykładowo u dziecka nr $4 \mathrm{w}$ wieku 5 lat oraz u dziecka nr 9 w wieku 4 lata zaobserwowano, że wartość progu uzyskana podczas pierwszego pomiaru wynosiła $25 \mathrm{~dB} \mathrm{HL}$ dla częstotliwości $8000 \mathrm{~Hz}$. W kolejnych pomiarach u tych dzieci wartości progu słyszenia dla tej częstotliwości wynosiły odpowiednio 15 i $5 \mathrm{~dB}$ HL.

W tabeli 1 przedstawiono średnie i odchylenia standardowe wartości progów wyznaczonych w kolejnych badaniach dla poszczególnych częstotliwości z podziałem na grupy wiekowe.

Przedstawione w tabeli 1 średnie wartości progów słyszenia uzyskane podczas trzeciego badania były nieznacznie niższe niż podczas badania 1 i 2 . Analiza statystyczna nie wykazała jednak, niezależnie od grupy wiekowej oraz częstotliwości, istotnych statystycznie zmian wartości progu słyszenia w kolejnych badaniach.

Na podstawie wartości progów uzyskanych w kolejnych pomiarach wyznaczono następujące wartości różnic:

- $\mathrm{R}_{1-2}$ - różnica pomiędzy drugim a pierwszym pomiarem, - $\mathrm{R}_{1-3}^{1-2}$ - różnica pomiędzy trzecim a pierwszym pomiarem, - $\mathrm{R}_{2-3}$ - różnica pomiędzy trzecim a drugim pomiarem.

Medianę oraz zakres (minimum i maksimum) różnic przedstawiono w tabeli 2 .

Wartość mediany dla poszczególnych wyznaczonych różnic u dzieci w wieku 5 lat wynosi $0 \mathrm{~dB}$, natomiast większość różnic zawierała się w granicach od -10 do $5 \mathrm{~dB}$. Dla pojedynczych osób dla określonych częstotliwości minimalne wartości różnic wynosiły $-15 \mathrm{~dB}$, natomiast maksymalne dodatnie różnice wynosiły $10 \mathrm{~dB}$.

W grupie dzieci 4-letnich wartość mediany dla większości różnic wynosiła $-5 \mathrm{~dB}$, a zakres różnic zawierał się w przedziale od -15 do $10 \mathrm{~dB}$. Jedynie u jednego dziecka różnica pomiędzy pierwszym i kolejnymi pomiarami wynosiła $20 \mathrm{~dB}$. 
Tabela 2. Mediana, wartość minimalna oraz maksymalna różnic pomiędzy progami słyszenia dla poszczególnych częstotliwości wyznaczonych w kolejnych badaniach z podziałem na grupy wiekowe

Table 2. Median and minimum and maximum difference between hearing thresholds for each frequency determined in each test repetition, by age-groups

\begin{tabular}{|c|c|c|c|c|c|c|c|c|c|c|}
\hline \multirow{2}{*}{ Wiek dziecka } & \multirow{2}{*}{ Częstotliwość } & \multicolumn{3}{|c|}{$\mathbf{R}_{1-2}$} & \multicolumn{3}{|c|}{$\mathbf{R}_{1-3}$} & \multicolumn{3}{|c|}{$\mathbf{R}_{2-3}$} \\
\hline & & Me & Min & Max & $\mathrm{Me}$ & Min & Max & Me & Min & Max \\
\hline \multirow{5}{*}{4 lata } & $500 \mathrm{~Hz}$ & $-2,5$ & -15 & 10 & $-5,0$ & -10 & 5 & $-5,0$ & -10 & 5 \\
\hline & $1000 \mathrm{~Hz}$ & 0,0 & -10 & 10 & $-5,0$ & -15 & 5 & $-5,0$ & -5 & 5 \\
\hline & $2000 \mathrm{~Hz}$ & $-5,0$ & -15 & 5 & $-5,0$ & -10 & 5 & 0,0 & -10 & 5 \\
\hline & $4000 \mathrm{~Hz}$ & 0,0 & -15 & 5 & $-2,5$ & -10 & 5 & $-5,0$ & -5 & 5 \\
\hline & $8000 \mathrm{~Hz}$ & 0,0 & -20 & 5 & $-5,0$ & -20 & 5 & $-5,0$ & -5 & 5 \\
\hline \multirow{5}{*}{5 lat } & $500 \mathrm{~Hz}$ & 0,0 & -10 & 10 & 0,0 & -10 & 5 & 0,0 & -10 & 5 \\
\hline & $1000 \mathrm{~Hz}$ & 0,0 & -10 & 0 & 0,0 & -15 & 0 & $-5,0$ & -10 & 0 \\
\hline & $2000 \mathrm{~Hz}$ & 0,0 & -10 & 5 & $-2,5$ & -10 & 0 & 0,0 & -5 & 5 \\
\hline & $4000 \mathrm{~Hz}$ & 0,0 & -5 & 5 & 0,0 & -10 & 0 & 0,0 & -10 & 0 \\
\hline & $8000 \mathrm{~Hz}$ & 0,0 & -10 & 5 & 0,0 & -10 & 5 & 0,0 & -10 & 0 \\
\hline
\end{tabular}

Tabela 3. Mediana, odchylenie standardowe oraz wartości maksymalne bezwzględnych różnic pomiędzy progami słyszenia w kolejnych pomiarach w grupie dzieci 4- i 5-letnich

Table 3. Median, standard deviation and maximum absolute difference between hearing thresholds in each test repetition in both groups

\begin{tabular}{ccccc}
\hline \multirow{2}{*}{ Częstotliwość } & 4-latki & \multicolumn{2}{c}{ 5-latki } \\
\cline { 2 - 5 } & Me & Max & Me & Max \\
\hline $500 \mathrm{~Hz}$ & 2,5 & 15 & 5,0 & 10 \\
\hline $1000 \mathrm{~Hz}$ & 5,0 & 15 & 5,0 & 10 \\
\hline $2000 \mathrm{~Hz}$ & 2,5 & 15 & 5,0 & 10 \\
\hline $4000 \mathrm{~Hz}$ & 5,0 & 15 & 2,5 & 10 \\
\hline $8000 \mathrm{~Hz}$ & 5,0 & 20 & 5,0 & 10 \\
\hline Dla wszystkich częstotliwości & 5,0 & 20 & 5,0 & 15 \\
\hline
\end{tabular}

Wykonane analizy statystyczne nie wykazały istotnego wpływu kolejnego pomiaru na wielkość wyznaczonej różnicy dla badanych częstotliwości, zarówno w grupie 5-latków, jak i 4-latków.

W tabeli 3 przedstawiono medianę oraz wartość maksymalną bezwzględnych wartości różnic pomiędzy progami słyszenia uzyskanymi w kolejnych pomiarach dla wszystkich badanych częstotliwości.

Przedstawione w tabeli 3 wartości mediany wartości bezwzględnej wszystkich wyznaczonych różnic pokazują, że połowa tych różnic nie przekraczała $5 \mathrm{~dB}$, przy czym u dzieci w wieku 4 lat występowały większe wartości maksymalnej różnicy. Na podstawie wszystkich różnic pomiędzy progami w poszczególnych pomiarach wyznaczono skumulowane wykresy tych różnic dla poszczególnych częstotliwości w obu grupach wiekowych (rycina 3 ).

Analiza skumulowanych rozkładów bezwzględnych wartości różnic pomiędzy progami wyznaczonymi w kolejnych badaniach wykazała, że u dzieci 5-letnich różnice progów $\leq 5 \mathrm{~dB}$ występowały u $80 \%$ badanych dzieci dla częstotliwości $500 \mathrm{~Hz}$ oraz u 90\% dla częstotliwości $4000 \mathrm{~Hz}$. Różnice nieprzekraczające $10 \mathrm{~dB}$ uzyskano w $100 \%$ przypadków dla częstotliwości 500, 2000, 4000 i $8000 \mathrm{~Hz}$. Dla częstotliwości $1000 \mathrm{~Hz}$ różnice nieprzekraczające $10 \mathrm{~dB}$ występowały w $93,3 \%$ przypadków.

W grupie dzieci 5-letnich odsetek różnic nieprzekraczających $5 \mathrm{~dB}$ dla większości częstotliwości wynosił ponad 83\%, natomiast dla częstotliwości $8000 \mathrm{~Hz}$ aż 93\%. 

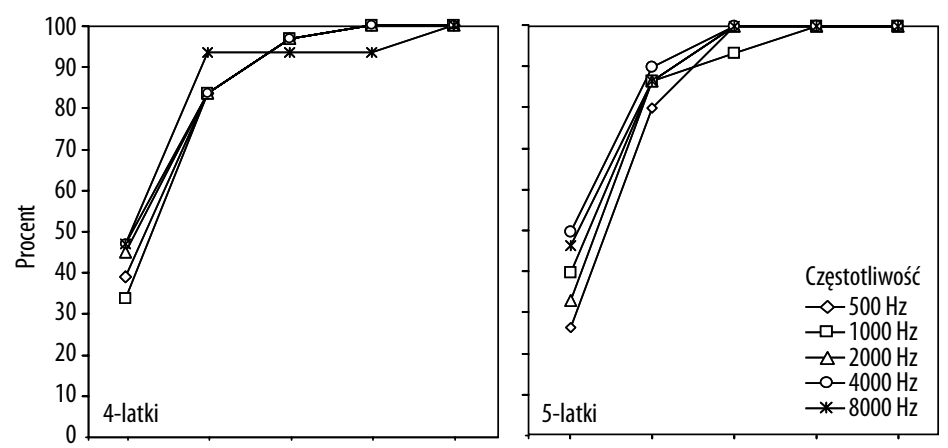

Rycina 3. Skumulowane wykresy wartości bezwzględnych różnic progów słyszenia dla badanych częstotliwości z podziałem na wiek

Figure 3. Cumulative diagrams of the absolute values of differences in hearing threshold for tested frequencies by age-groups
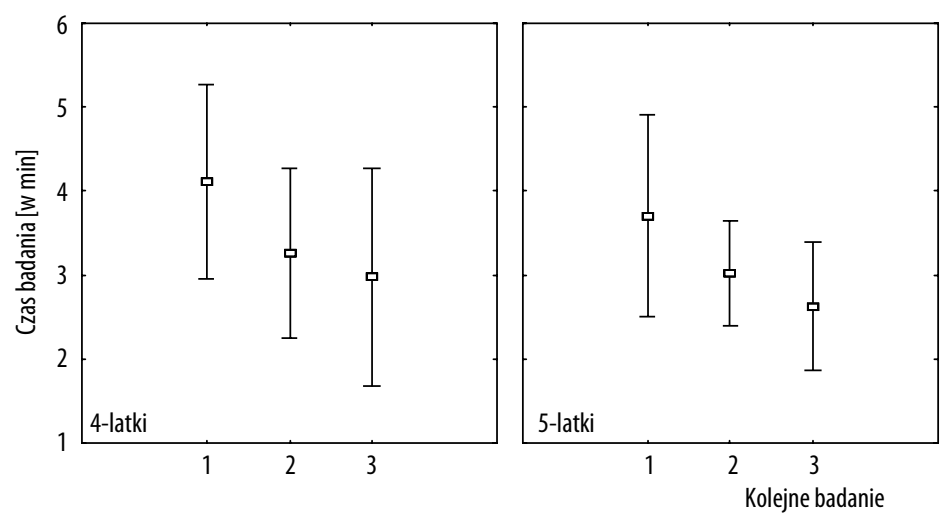

Rycina 4. Średnie wartości oraz 95\% przedział ufności czasów wykonywania kolejnych badań

Figure 4. Mean values and 95\% confidence interval of time need for each repetition of tests

Różnice nieprzekraczające $10 \mathrm{~dB}$ występowały w ponad 96\% przypadków.

Na rycinie 4 przedstawiono średnie wartości oraz odchylenie standardowe czasów trwania pomiarów audiometrycznych w jednym uchu w kolejnych próbach u dzieci 4- i 5-letnich.

Z wyników przedstawionych na rycinie 4 wynika, że w obu grupach średnie czasy pomiarów zmniejszały się wraz z kolejnym pomiarem, przy czym różnice istotne statystycznie występowały między 1 i 3 pomiarem w obu grupach wiekowych.

\section{Dyskusja i wnioski}

Zgodnie z konkluzją Rady Europy podpisaną w grudniu 2012 roku zaleca się wdrażanie programów badań przesiewowych słuchu, wzroku i mowy u dzieci w wieku przedszkolnym i szkolnym [32,33].

W niniejszej pracy podjęto próbę oceny powtarzalności wyników badań audiometrycznych wykonywanych w warunkach przedszkolnych, a także oszacowano czas wykonania takiego badania. Biorąc pod uwagę fakt, że dla badanych dzieci były to pierwsze $\mathrm{w}$ życiu audiometryczne badania słuchu, założono, że w kolejnych pomiarach wartości progu słyszenia powinny być coraz niższe.

Analiza statystyczna wyników wykazała, że średnie wartości progów wyznaczone dla kolejnych trzech pomiarów nie różnią się między sobą istotnie statystycznie w obu grupach wiekowych. Średnie wartości progów dla kolejnych pomiarów są nieznacznie niższe (lepsze), co może mieć związek z przyzwyczajeniem się dziecka do dźwięków i nowej dla niego sytuacji oraz zdobyciem przez małego pacjenta doświadczenia.

Wartość mediany wyznaczonych różnic pomiędzy pomiarami dla większości częstotliwości w obu grupach wiekowych wynosiła $0 \mathrm{~dB}$. Zaobserwowane w badanym materiale występowanie zarówno dodatnich, jak i ujemnych różnic świadczy o tym, że dla kolejnych badań wyznaczone wartości progu słyszenia były zarówno lepsze, jak i gorsze. Zgodnie z przyjętą procedurą wielkość zmiany natężenia bodźca podczas badania progowego wynosiła $5 \mathrm{~dB}$. Założono, że większość zmian wartości progów słyszenia pomiędzy poszczególnymi pomiarami powinna zawierać się w granicach \pm 5 , czyli w zakresie $10 \mathrm{~dB}$.

Przedstawione na rycinie 3 skumulowane wykresy bezwzględnych wartości wyznaczonych różnic pomiędzy wszystkimi pomiarami dla badanych częstotliwości wskazują, że ponad $80 \%$ tych różnic dla wszystkich częstotliwości w obu grupach wiekowych nie przekraczało $5 \mathrm{~dB}$, a ponad $93 \% \mathrm{z}$ nich zawierało się $\mathrm{w}$ przedziale do $10 \mathrm{~dB}$, co jest równoważne $\mathrm{z}$ wielkością błędu związanego $\mathrm{z}$ zastosowaną procedurą badania oraz nieistotne $\mathrm{z}$ klinicznego punktu widzenia.

W badaniach innych autorów, oceniających powtarzalność audiometrii progowej dla różnych grup wiekowych oraz różnych typów przetworników elektroakustycznych, uzyskiwane wielkości różnic pomiędzy kolejnymi pomiarami były zbliżone do wyników niniejszej pracy.

W pracy Landry (1999) badano m.in. wielkości różnic pomiędzy dwoma kolejnymi pomiarami. Przedstawione 
wielkości różnic były zgodne z wynikami niniejszej pracy, podobnie jak zaobserwowany brak różnic istotnych statystycznie [34].

W pracy Javellana (2008) badano korelację pomiędzy progiem słyszenia wyznaczonym za pomocą wirtualnego audiometru a wynikami uzyskanymi audiometrem klinicznym w kabinie audiometrycznej. Uzyskano silną dodatnią korelację, co autorzy pracy określili jako wynik potwierdzający dobrą powtarzalność obu wykonywanych pomiarów. W niniejszej pracy oceny wiarygodności dokonano na podstawie bezwzględnych wartości różnic, których zakres również potwierdza dużą zgodność pomiędzy pomiarami [35].

W pracy Stuart (1990) porównano powtarzalność audiometrii progowej dla słuchawek wokółusznych i wewnątrzusznych, w różnych grupach wiekowych. Średnie oraz odchylenie standardowe wielkości różnic dla słuchawek HDA-200 były zbliżone do wyników niniejszej pracy. Nie wykazano różnic istotnych statystycznie pomiędzy kolejnymi pomiarami [36].

Podobne badania prowadzili Schmuziger i wsp. (2004), porównując progi słyszenia uzyskane za pomocą słuchawek
Sennheiser HDA 200 i Etymotic Research ER-2 Earphones. Jak wykazano, powtarzalność wyników w zakresie częstotliwości od $0,5 \mathrm{kHz}$ do $16 \mathrm{kHz}$ była podobna dla obu przetworników i niewiele, ale istotnie wzrosła na najwyższych częstotliwościach, szczególnie przy $16 \mathrm{kHz}$ [37].

Jak wykazała analiza czasów poszczególnych pomiarów, czas wykonania badania skraca się $\mathrm{z}$ kolejnym pomiarem (rycina 4), co potwierdza założenie, że pierwszy pomiar słuchu może stwarzać problemy dla małego dziecka. Jednak pomimo dłuższego czasu potrzebnego na wykonanie pierwszego badania, już wynik tego badania może być uznawany za wiarygodny.

Na podstawie uzyskanych wyników sformułowano następujące wnioski:

1. Wraz z kolejnym pomiarem obserwuje się niewielkie zmniejszanie wartości progu słyszenia.

2. Pomiary progu słyszenia u dzieci w wieku przedszkolnym charakteryzują się znaczną powtarzalnością.

3. W kolejnych badania zaobserwowano skracanie czasu wykonywania badań, przy czym większe w grupie 4-latków niż dzieci 5-letnich.

4. U dzieci w wieku 4 i 5 lat możliwe jest uzyskanie wiarygodnego badania audiometrycznego.

\section{Piśmiennictwo:}

1. Hinchcliffe R. The age function of hearing-aspects of the epidemiology. Acta Otolaryngol Suppl, 1990; 476: 7-11.

2. Śliwińska-Kowalska M. Audiologia kliniczna. Łódź: Mediton; 2005.

3. Weinstein B, Presbycusis. W: Katz J, red. Handbook of clinical audiology. Lippincott Williams \& Wilkins; 1994: 568-84.

4. Willott JF. Anatomic and physiologic aging: A behavioural neuroscience perspective. J Am Acad Audiol, 1996; 7: 141-51.

5. Badania przesiewowe słuchu http://www.sponin.org. pl/index_2011.php http: //www.sponin.org.pl/index. php?badania_przesiewowe

6. Badania przesiewowe słuchu u noworodków http: //www.ifps. org.pl/web/aktualnosci.php?news $=$ news_detailse $r i d=222$

7. Kochanek K. Badania przesiewowe słuchu. W: Śliwińska-Kowalska M, red. Audiologia kliniczna. Łódź: Mediton; 2005, 391-6.

8. Kochanek K. Diagnostyka narządu słuchu. W: Janczewski G, red. Otorynolaryngologia praktyczna. Gdańsk: Via Medica; 2007: 12-25.

9. Skarżyński PH, Kochanek K, Skarżyński H, Senderski A, Wysocki J, Szkiełkowska A i wsp. Hearing screening program in school age children in western Poland. Int Adv Otol, 2011; 7(2): 194-200.

10. Bamford J, Fortnum H, Bristow K, Smith J, Vamvakas G, Davies $\mathrm{L}$ i wsp. Systematic review of the effectiveness of school entry hearing screening. W: Current practice, accuracy, effectiveness and cost effectiveness of the school entry hearing screen. Health Technol Assess, 2007; 11(32): 31-48.

11. European Consensus Statement on Hearing Screening of Pre-School and School-Age Children. Int J Pediatr Otorhinolaryngol, 2012; 76(1): 120-1.

12. European Consensus Statement on Hearing, Vision, and Speech Screening in Pre-school and School-age Children. JHS, 2011; 1(2). http://www.journalofhearingscience.com.
13. Konkluzja Rady Europejskiej dotycząca wyrównywania szans dzieci z uszkodzeniami komunikacyjnymi. Official Journal of the European Union: http://eurlex.europa.eu/LexUriServ/LexUriServ.do?uri=OJ: C: 2011: 361: 0009: 0010: EN: PDF.

14. McCann DC, Worsfold S, Law CM, Mullee M, Petrou S, Stevenson J i wsp. Reading and communication skills after universal newborn screening for permanent childhood hearing impairment. Arch Dis Child, 2009; 94: 293-7.

15. Pastorino G, Sergi P, Mastrangelo M, Ravazzani P, Tognola G, Parazzini M i wsp. The Milan Project: A newborn hearing screeaning programme. Acta Pediatr, 2005; 94: 458-63.

16. Weber BA, Diefendor A. Newborn Hearing Screening. W: Musiek FE, Rintelmann WF, red. Contemporary perspectives in hearing assessment. 1999; 327-47.

17. Kruszyńska M, Kochanek K, Piłka A, Skarżyński H. Zależność pomiędzy wynikami badań przesiewowych wykonywanych w okresie noworodkowym i szkolnym. Nowa Audiofonologia, 2013; 2(4): 44-8.

18. Tarshish Y, Leschinski A, Kenna M. Pediatric sudden sensorineural hearing loss: diagnosed causes and response to intervention. Int J Pediatr Otorhinolaryngol, 2013; 77(4): 553-9.

19. Niskar AS, Kieszak SM, Holmes A, Esteban E, Rubin C, Brody DJ. Prevalence of hearing loss among children 6 to 19 years of age: the Third National Health and Nutrition Examination Survey. JAMA, 1998; 279(14): 1071-5.

20. Bess FH. The minimally hearing-impaired child. Ear Hear, 1985; 6(1): 43-7.

21. Oyewumi AM, Adejumo OR. An investigation of hearing loss among school age children through audiological assesment in Ibadan, Oyo State, Nigeria. Elementary Education Online, 2011; 10(1): 1-11.

22. Taljaard DS, Leishman NF, Eikelboom RH. Personal listening devices and the prevention of noise induced hearing loss in children: the Cheers for Ears Pilot Program. Noise Health, 2013; 15(65): 261-8. 
23. Morata TC. Young people: their noise and music exposures and the risk of hearing loss. Int J Audiol, 2007; 46(3): 111-2.

24. Clemens CJ, Davis SA. Minimizing false-positives in universal newborn hearing screening: A simple solution. Pediatrics, 2001; 107: 3-29.

25. Davis JM, Elfenbein J, Schum R, Bentler RA. Effects of mild and moderate hearing impairments on language, educational, and psychosocial behavior of children. J Speech Hear Disord, 1986; 51: 53-62.

26. Mozafar S, Khashayar A. A practical screening model for hearing loss in Iranian school-aged children. World J Pediatr, 2009; 5(1): 46-50.

27. Śliwa L, Hatzopoulos S, Kochanek K, Piłka A, Senderski A, Skarżyński PH. A comparison of audiometric and objective methods in hearing screening of school children. A preliminary study. Int J Pediatr Otorhinolaryngol, 2011; 75(4): 483-8.

28. Jędrzejczak WW, Piotrowska A, Kochanek K, Śliwa L, Skarżyński H. Low-frequency otoacoustic emissions in schoolchildren measured by two commercial devices. Int J Pediatr Otorhinolaryngol, 2013; 77(10): 1724-8.

29. Piłka E, Trzaskowski B, Jędrzejczak WW, Kochanek K, Skarżyński H. Wykorzystanie emisji otoakustycznych w badaniach przesiewowych u dzieci w wieku 6-13 lat w odniesieniu do wyników audiometrii tonalnej i impedancyjnej. Otorynolaryngologia - przegląd kliniczny, 2012; 11(1): 7-12.
30. Jędrzejczak WW, Kochanek K, Śliwa L, Piłka E, Piotrowska A, Skarżyński H. Chirp-evoked otoacoustic emissions in children. Int J Pediatr Otorhinolaryngol, 2013; 77(1): 101-6.

31. Martin FN. Introduction to Audiology. $3^{\text {rd }}$ edition. Englewood Cliffs, NJ: Prentice-Hall Inc.; 1986.

32. Skarżyński H, Piotrowska A. Screening for pre-school and school-age hearing problems: European Consensus Statement. Int J Pediatr Otorhinolaryngol, 2012; 76(1): 120-1.

33. Skarżyński H, Piotrowska A. Prevention of communication disorders - screening pre-school and school-age children for problems with hearing, vision and speech: European Consensus Statement. Med Sci Monit, 2012; 18(4): 17-21.

34. Landry JA, Green WB. Pure-tone audiometric threshold test-retest variability in young and elderly adults. J Speech Lang Pathol Audiol, 1999; 23(2): 74-80.

35. Javellana AEM, Casile RU. The correlation of results between pure tone audiometry and the virtual audiometer: A simulated air-conduction clinic-based audiometer. Philipp J Otolaryngol Head Neck Surg, 2008; 23(1): 9-14.

36. Stuart A, Stenstrom R, Tompkins C, Vandenhoff S. Test-retest variability in audiometric threshold with supraaural and insert earphones among children and adults. Audiology, 1991; 30: 82-90.

37. Schmuziger N, Probst R, Smurzynski J. Test-retest reliability of pure-tone thresholds from 0.5 to $16 \mathrm{kHz}$ using Sennheiser HDA 200 and Etymotic Research ER-2 Earphone. Ear Hear, 2004; 25(2): 127-32. 